\title{
Working in tandem: Proportionality and procedural guarantees in EU immigration law
}

\author{
Johan Rochel*
}

(Received 07 August 2017; accepted 11 November 2017)

\begin{abstract}
This Article aims at highlighting theoretical and practical issues around the application of the general principle of proportionality in EU immigration. It focuses on the application procedure foreseen by the Single Permit Directive by proposing an argument that combines proportionality and procedural guarantees. This Article has two main objectives: First, it explains why and how the general principle of proportionality is applicable to first admission applications. In this context, the Single Permit Directive-adopted as an important piece of the emerging EU legal regime on immigration-will represent a common theme for our reflections and a timely example on the practical implications of the argument presented in this Article. Second, it explores an important dimension of the legal-philosophical relevance of proportionality as applied to immigration. This specific Article might be apprehended from the point of view of a larger debate on the meaning of discretion in immigration law. It connects to the field of immigration ethics, a field in which legal scholars should become more active. As will be shown, ethical and legal considerations on immigration should work closely together, thereby improving current regulations and their implementation.
\end{abstract}

Keywords: migration law; European Union; proportionality; migration ethics; jurisdiction

\section{A. Introduction}

The conjunction of labor immigration and proportionality might cause a few sparks to fly. On one hand, a political and legal field in which a public authority is claiming wide discretion in deciding who is to be accepted on its territory for work purposes; on the other hand, a strong principle linked to the rule of law and considered as a pillar of the legitimacy of a public authority. When interfering with individuals, a legitimate public authority shall do no more than what is necessary to achieve specific objectives, assuming it is legitimate. But what happens when we apply this principle to the application submitted by a potential immigrant worker?

This Article addresses an underexplored function of the principle of proportionality in immigration matters. Although proportionality is a well-known principle in several contexts related to immigration, the main hypothesis is that its relevance for the first admission application formulated by potential immigrants is still to be emphasized. A consistent application of proportionality to this application would lead to challenging conclusions for a certain understanding of discretion in immigration matters.

Johan Rochel is a Postdoc researcher, Faculty of Law, University of Zürich https://www.ivr.uzh.ch/de/institutsmitglieder/ oesch/Postdoc-Researchers.html. Email: johan.rochel@gmail.com

${ }^{*}$ Many thanks to Dr. Stefan Schlegel, Dr. Benedikt Pirker, Dr. Bas Schotel, Stéphanie Colella and the reviewers and editors of the German Law Journal.

() 2019 The Author. Published by Cambridge University Press on behalf of the German Law Journal. This is an Open Access article, distributed under the terms of the Creative Commons Attribution licence (http://creativecommons.org/licenses/by/4.0/), which permits unrestricted re-use, distribution, and reproduction in any medium, provided the original work is properly cited. 
This Article aims at highlighting theoretical issues underlying the general principle of proportionality, while apprehending them in the context of the current EU immigration regime. More specifically, the objective of this Article is twofold. First, it aims at formulating an argument on the applicability of proportionality as a general principle to first admission application cases. Drawing upon general principles in making the most out of current immigration norms shall prove interesting for practitioners engaged into what Costello and others call "strategic litigation." General principles are a medium to assert how to improve procedural guarantees using an analogy to the case of the Asylum Procedures Directive. Costello brings this idea to the point in framing her argument around general principles, which she labels as "in action." Similarly, Bast refers to general principles as a potential route for the sake of bringing about a strong version of procedural rights. ${ }^{3}$ This Article aims at formulating a similar claim with respect to the relevance of proportionality in conjunction with procedural guarantees: In action and in tandem. As I shall argue, the Single Permit Directive-adopted as an important piece of the emerging EU legal regime on immigration-will represent a common theme for our reflections and a timely example on the practical implications of the argument presented in this Article.

Second, this Article explores an important dimension of the legal-philosophical relevance of proportionality as applied to immigration. This specific Article might be apprehended from the point of view of the "legal turn" in immigration ethics, which I have advocated in another contribution. ${ }^{4}$ Ethical and legal considerations on immigration shall work closely together, thereby improving current regulations and their implementation.

These hypotheses are to be developed in two main arguments. First, I shall address the issue of applicability of proportionality to the entry point, for example when potential immigrants submit an application to immigrate to one of the Member States of the EU. For that objective, I distinguish three dimensions of the applicability of proportionality: As a jurisdictional issue, as an issue pertaining to the applicability of general principles of EU law, and as an issue pertaining to the nature of the interests upon which proportionality is supposed to bear. These three dimensions shall offer a reply to three types of skepticism about the applicability of the proportionality qua general principle of EU law to issues of first admission into the EU. By paying due attention to the relevance of the Single Permit Directive and its procedural guarantees, I conclude the first part by showing that the general principle of proportionality is applicable to the majority of applications of labor immigration to the EU. More specifically, I argue that the principle is applicable to the procedural interests created by the existence of an EU law procedure.

Second, I explore the joint application of proportionality with the procedural guarantees foreseen by this procedure. Focusing on the right to get a reasoned decision by a public authority, I will show that proportionality should be drawn upon by exercising normative pressure towards better documented decisions. This work-in tandem-shall prove powerful when arguing for better documented decisions from the standpoint of improving underlying factual and empirical consideration in a decision. I conclude this second part by highlighting the general role that proportionality might play in improving procedural guarantees and setting limits to a certain understanding of discretion in immigration matters.

For two reasons, my argument is to be developed in the context of EU immigration law. First, the case of the EU is particularly interesting in light of the importance of general principles-not least thanks to their transversality — and the general principle of proportionality. ${ }^{5}$ Second, the case

\footnotetext{
${ }^{1}$ See Cathyrn Costello, The Asylum Procedures Directive in Context: Equivocal Standards Meet General Principles, in WHOSE Freedom, Security and Justice? EU Immigration AND Asylum LaW and Policy 193 (Anneliese Baldaccini, et al. eds., 2007).

${ }^{2} I d$.; See also Evelien Brouwer, Effective Remedies for Third Country Nationals in EU Law: Justice Accessible to All?, in The First Decade of EU Migration and Asylum Law 396-399 (Elspeth Guild \& Paul Minderhoud eds., 2012).

${ }^{3}$ Jurgen Bast, Of General Principles and Trojan Horses - Procedural Due Process in Immigration Proceedings under EU Law, 11 GERMAn L.J. 1006 (2010).

${ }^{4}$ Source omitted (Anonymous review).

${ }^{5}$ On the cross-fertilization effect of principle see XAVIER Groussot, GENERAL Principles of COMMUNITY LAW 421 (Europa Law Publishing 2006); see also Armin von Bogdandy \& Jürgen Bast, Principles of European Constitutional LaW
} 
of the EU is promising because of the profound legal, but also political and-one might dare to say-philosophical transformations of the way national borders and sovereign prerogatives on immigration are reframed. ${ }^{6}$ In a legal-theoretical dimension, my argument could clearly be applied by analogy to a national context. The applicability and application of proportionality to the way national authorities are, in general, dealing with applications submitted by potential immigrant would call for similar implications.

\section{B. Proportionality as a key principle in immigration}

In many immigration-related contexts, the applicability of proportionality as a key principle of EU law is uncontroversial. Proportionality has long been applied to the issue of free movement within the EU, as well as to family reunification of third-country nationals (TCNs). Similarly, proportionality is a key principle when it comes to the deportation of TCNs residing within a European state. The applicability of the principle of proportionality to these cases is uncontroversial because three important conditions are fulfilled: (1) The cases at stake are clearly within the jurisdiction of a political community - such as the sponsor in the case of the family reunification and the TCN to be deported in the deportation case; (2) the interests affected are legally recognized and accordingly protected as a right; and (3) the situations at stake are within the ambit of EU law and general principles are hence applicable.

In contrast, the present argument addresses situations in which the relevant public authority is claiming wide discretion in accepting or rejecting applications for admission, namely the case of a potential labor immigrant applying for a residence and work permit in the EU. ${ }^{7}$ Imagine the case of an Indian IT specialist submitting an application in accordance with the Single Permit Directive and the Blue Card Directive. ${ }^{8}$ Two questions should be asked: Is the principle of proportionality applicable in the first place and, if so, what does that mean? To address the first question, I distinguish three dimensions of the applicability of proportionality: As an issue of jurisdiction, as an issue pertaining to the applicability of general principle of EU law, and as an issue pertaining to the nature of the interests upon which proportionality is supposed to bear. These three dimensions shall offer a reply to three types of skepticism about the applicability of proportionality qua general principle of EU law to issues of first admission to the EU.

It is important to note that this investigation is relevant regardless of the exact extent of this claimed discretion. As the Court of Justice of the European Union-CJEU-has recalled in shortterm visa constellations - visa and Schengen borders code ${ }^{9}$ - and in the case of the Students

(Hart Publishing 2010). Considered as "instruments of constitutional dialogue, general principles facilitate the constant renewal of the EU legal order, epitomizing the 'EU's living constitution.” Koen Lenaerts \& Jose A. Gutiérrez-Fons, The Constitutional Allocation of Powers and General Principles of EU Law, 47 Common Mkt. L Rev. 1629, 1669 (2010).

${ }^{6}$ For a broader theoretical framing, see Johan Rochel, Une lecture kantienne de la libre-circulation, JUSLETTER 1 (2013).

${ }^{7}$ For a similar focus, see Jurgen Bast, Aufenthaltsrecht und Migrationssteuerung, in Jus Publicum 207 181(Mohr, Siebeck ed., 2011). This in turn relates to the broader issues of discretion and sovereignty in immigration matters. For a complete analysis of this assumption, see SYLVIE SAROLÉ, DROITS DE L'HOMME ET MIGRATIONS: DE LA PROTECTION DU MIGRANT AUX DROITS DE LA PERSONNE MIGRANTE 466-468 (Bruylant 2006); Jean-François Flauss, L'étranger, entre souveraineté nationale et droits de l'homme, IN L'ÉTRANGER FACE AU DROIT: XXEs JOURNÉES D'ÉTUDES JURIDIQUES JEAN DABIN 1, 48 (Bruylant, 2010). It is interesting to note that David Miller-albeit being a rather critical thinker in matters of immigration-explicitly renounces using the concept of sovereignty because it would "suggest that the state is subject to no restrictions in its treatments of potential immigrants.” David Miller, National Responsibility and Global Justice 216 (Oxford University Press, 2007).

${ }^{8}$ Directive 2011/98, of the European Parliament and of the Council of 13 December 2011 on a Single Application Procedure for a Single Permit for Third-Country Nationals to Reside and Work in the Territory of a Member State and on a Common Set of Rights for Third-Country Workers Legally Residing in a Member State, 2011 O.J. (L 343); Council Directive 2009/50/EC, of the European Parliament and of the Council of of 25 May 2009 on the conditions of entry and residence of third-country nationals for the purposes of highly qualified employment, 2009 O.J. (L 155).

${ }^{9}$ The Court ruled that the list of criteria to assess an application was exhaustive; while recognizing the margin of appreciation in the assessment of these criteria: Case C-84/12, Koushkaki v. Bundesrepublik Deutschland, 2013 EUR-Lex CELEX 
Directive, ${ }^{10}$ Member States are bound by the substantive conditions, which the EU legislator has laid down. If the conditions are fulfilled, the person shall be granted a right to enter and stay-visa or other. Nevertheless, while recognizing that the list of conditions to be fulfilled is exhaustive, the Court has also made it clear that the Member States retain a wide margin of discretion in assessing these conditions. Furthermore, most relevant for our present focus on labor immigration, the Court has not addressed this issue in the context of the Blue Card Directive with regard to conditions of stay, but also to the competence withheld by Member States in determining the volume of admission. The argument presented herein remains valid regardless of the future answer given to these central questions.

First, I shall briefly recall what the general principle of proportionality encompasses as a matter of EU law, before discussing the three dimensions of applicability of the principle of proportionality to immigration cases.

\section{Proportionality in EU law}

In the context of EU law, the principle of proportionality has been recognized early on as a general principle. ${ }^{11}$ In its usual formulation, the CJEU defines it as follows: "[T]he principle of proportionality, which is one of the general principles of European Union law, requires that measures implemented by acts of the European Union are appropriate for attaining the objective pursued and do not go beyond what is necessary to achieve it." 12 This understanding makes the link between the principle of proportionality and the rule of law particularly strong. In Internationale Handelsgesellschaft, the CJEU required that "the individual should not have his freedom of action limited beyond the degree necessary in the public interests." ${ }^{3}$ In EU law, the proportionality test is conceived with three parts: Suitability, necessity, and proportionality stricto sensu (s.s.). Following the position developed by Craig, there is evidence to show that the three parts of the test play an important role in EU law, although the third part-s.s. - is less commonly used explicitly. ${ }^{14}$ Specifically, it is only used in a subsidiary way if the conditions of suitability and necessity are shown as fulfilled.

Following Tridimas, the principle of proportionality is considered to fulfil three core functions in EU law, each function in turn protecting distinct underlying interests. ${ }^{15}$ First, it represents a ground for the review of Union measures. In this first case, authorities are called to consider private interests $v i s-\grave{a}$-vis public interests. Second, it provides a ground for the review of national measures affecting fundamental freedoms protected by EU law. In this case, authorities are called

LEXIS 862 (Dec. 19, 2013); Case C-575/12, Air Baltic Corporation AS v. Valsts robežsardze, 2014 EUR-Lex CELEX LEXIS 2155 (Sept. 4, 2014).

${ }^{10}$ Case C-491/13, Mohamed Ali Ben Alaya v. Bundesrepublik Deutschland, 2014 EUR-Lex CELEX LEXIS 2187 (Sept. 10 , 2014).

${ }^{11}$ See Case C 11-70, Internationale Handelsgesellschaft mbH v. Einfuhr- und Vorratsstelle für Getreide und Futtermittel, 1970 E.C.R. 1125; See also Tor-Inge Harbo, The Functin of the Proportionality Principle in EU Law, 16 EUR L. J. 158,164 (2010); TAkis Tridimas, The General Principles of EU LaW 141-42 (Oxford Universtiy Press, 2007); Stefan Vogenauer \& Stephen Weatherill, General Principles of Law: European and Comparative Perspectives (Studies of the Oxford Institute of European and Comparative Law) (Hart Publishing Ed. 2017).

${ }^{12}$ Joined Cases 92/09 \& 93/09, Volker und Markus Schecke GbRHartmut Eifert v. Land Hessen, 2010 E.C.R. I-11063.

${ }^{13}$ See Case C 11-70, supra note 11.

${ }^{14}$ Paul Craig, EU Administrative Law 601-04 (Oxford University Press, 2012); For the arguments advanced by the AG, see Case C-159/90, The Soc'y for the Prot. of Unborn Children Ireland Ltd. v. Stephen Grogan \& others, 1991 ECR I-04685; Takis Tridimas, The General Principles of EU Law 139 (Oxford Universtiy Press, 2007) (Tridimas is more sceptical and argues that "in practice the Court does not distinguish in its analysis between the second and the third test).

${ }^{15}$ Tridimas, supra note 14; For a similar distinction, see XAvier Groussot, GenERAL PrinCIPLES OF COMMUNITy LAW 151 (Europa Law Publishing 2006); Paul Craig, EU Administrative LaW 590 (Oxford University Press, 2012); Tor-Inge Harbo, The Function of the Proportionality Principle in EU Law, 16 EUR L. J. 158, 173 (2010) (Harbo proposes considering the different cases of application from a functional perspective). 
to consider the Union vis-à-vis national interests. Third, proportionality is used to control the exercise of the Union's competences. ${ }^{16}$ The focus of this Article will be on the principle of proportionality fulfilling the first function. This might entail measures taken by EU institutions and by Member States acting within EU law that affect individuals. The two other functions will not be directly considered for the time being. ${ }^{17}$

It is undisputed that the principle of proportionality, in its first identified function, is a key principle in many immigration-related contexts. Two contexts are especially relevant and have been the objects of both important case law and literature. First, proportionality has long been applied to the issue of deportation. In the case law by the European Court of Human Rights (ECtHR), one finds numerous cases in which the relevance of proportionality is underlined. As developed by the ECtHR in the influential Boultif case, ${ }^{18}$ this requirement to act in a proportionate way requires from the public authority to take into account-in a range of relevant elements - an individual assessment which includes: The nature and seriousness of the offense, the duration of residence in the host country, the period of time that has passed since the offense and the applicant's conduct during that period, the nationalities of the various persons concerned, and the applicant's family situation. ${ }^{19}$ As defined above, the key insight is to recognize that a public authority should interfere in the least harmful way necessary to attain its objective.

Second, the principle of proportionality has been essential for the internal free movement of EU citizens. As foreseen by Directive 2004/38, ${ }^{20}$ the right to free movement enjoyed by all EU citizens is not unconditional and should be interpreted in light of the main premise of the free movement regime, according to which, inter alia, a moving Union citizen shall not become a financial burden to the hosting State. ${ }^{21}$ These conditions are based upon the legitimate interest of Member States in preserving their financial resources. In the case law of the CJEU, these conditions have been interpreted in accordance with the general principles of EU law-most importantly the principle of proportionality. ${ }^{22}$ This is especially true in arbitrating conflicting objectives between free movement and access to state welfare provisions. In addressing this challenge, the Court has developed what could be called a "gradual integration" approach, ${ }^{23}$ which in turn could make sense of the firmer stance on inactive EU citizens adopted in the latest cases. ${ }^{24}$ The approach chosen by the Court is based on the principle of proportionality in outlining a method that takes into account

\footnotetext{
${ }^{16} \mathrm{See}$ Treaty of Lisbon Amending the Treaty on European Union and the Treaty Establishing the European Community, Dec. 13,2007, 2007 O.J. (C 306) art. 5(4) [hereinafter TFEU]; Treaty on the Functioning of the European Union, Protocol Number 2 on the Application of the Principles of Subsidiarity and Proportionality, May 9,2008, 2008 O.J. (C 115).

${ }^{17}$ On proportionality and national measures interfering with fundamental freedoms, see TRIDIMAS, supra note 14 , at 193-241; On proportionality in connection with the exercise of competences see XAVIER Groussot, GENERAL PRINCIPLES of Community Law 145-46 (Europa Law Publishing 2006); Takis Tridimas, The General Principles of EU Law 175-92 (Oxford Universtiy Press, 2007).

${ }^{18}$ Boultif v. Switzerland, 2001-IX Eur. Ct. H.R. 54273.

${ }^{19}$ For subsequent case-law see Yildiz v Austria, 2002 Eur. H.R. 37295/97; Amrollahi v. Denmark, 2002 Eur. H.R. 56811/00; Onur v. The United Kingdom, 2009 Eur. H.R. 27319/07.

${ }^{20}$ Directive 2004/38, of the European Parliament and of the Council of 30 April 2004 on the Right of Citizens of the Union and Their Family Members to Move and Reside Freely Within the Territory of the Member State, 2004 O.J. (L 158).

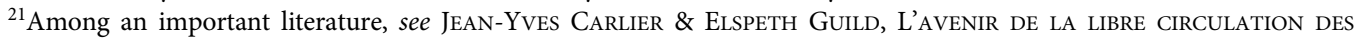
PERSONNES DANS L'U.E. (2d ed., 2006); Ferdinand Wollenschläger, A New Fundamental Freedom beyond Market Integration: Union Citizenship and its Dynamics for Shifting the Economic Paradigm of European Integration, 17 EuR. L.J. 1 (2011).

${ }^{22}$ Case C-413/99, Baumbast \& R v. Sec'y of State for the Home Dep't 2002 E.C.R. I-07091; Joined Cases 523/11 \& 85/11, Laurence Prinz v. Region Hannover and Philipp Seeberger v. Studentenwerk Heidelberg, 2013 EUR-Lex CELEX LEXIS 524 (July 18, 2013); See Jean Yves Carlier, Quels progrès pour les libertés?, in D’AMSTERDAM À LisBONNE: DIX ANS D'ESPACE DE LIBERTÉ, DE SÉCURITÉ ET DE JUSTICE 83, 89 (2010).

${ }^{23}$ Case C-158/07, Förster v. Hoofddirectie van de Informatie Beheer Groep 2008 E.C.R. I-08507; Case C-103/08, Gottwald v. Bezirkshauptmannschaft Bregenz, 2009 E.C.R. 2009 I-09117.

${ }^{24}$ Case C-333/13, Elisabeta \& Florin Dano v. Jobcenter Leipzig, 2014 EUR-Lex CELEX LEXIS 2358 (Nov. 11, 2014) (the right to reside was recalled to rely upon having sufficient resources and not becoming a burden for the host Member State).
} 
both the EU citizen's degree of integration in the host Member State and the nature of the social benefit at stake. ${ }^{25}$

With this very brief overview in mind, we shall address the three dimensions of applicability.

\section{Defining jurisdiction}

For our present investigation, the objective of the discussion on the concept of jurisdiction is to highlight the crucial relevance of a certain relationship between an individual - the potential immigrant - and a public authority - the EU. ${ }^{26}$ In brief, jurisdiction is handled as a normative threshold. As Besson writes with respect to the applicability of fundamental rights, jurisdiction "conditions the applicability of those rights and duties on political and legal circumstances where a certain relationship exists between right-holders and states parties." ${ }^{27}$ In the context of immigration as in other contexts in which a public authority interacts with individuals, the question of jurisdiction is essential to establish whether the relationship between the two is of a relevant type in the context of fundamental rights' obligations. In order for these obligations to be triggered, it shall be shown that a particular rights-bearer is in a specific relationship with a particular public authority, which exercises legal and political authority over them. More specifically, three constitutive elements of jurisdiction shall be assessed: (1) Power by a public authority shall be effective and exercised; (2) this power shall be exercised overall, and not only from time to time; and (3) this power shall be normative: It shall give reasons for actions. ${ }^{28}$

This understanding of jurisdiction and its link to extraterritoriality is particularly relevant in regards to asylum protection. ${ }^{29}$ The EU and its Member States have developed control and "prevention" practices outside of their territorial borders which amounts-for many commentators-to the exercise of state power over asylum seekers. ${ }^{30}$ This supposes that the jurisdiction threshold should be considered as reached. The legal and political relevance of the question is focused on the level of protection which should be granted to asylum seekers who are found to be under

\footnotetext{
${ }^{25}$ For a similar approach, see Francis Jacobs, Citizenship of the European Union-A Legal Analysis, 13 EuR. L. J. 591 (2007). Verschueren opposes this gradation scheme to a "perfect assimilation" model in which Union citizens would be entitled to full equal treatment as soon as they settle. Herwig Verschueren, EU Free Movement of Persons and Member States' Solidarity Systems: Searching for a Balance, in The First Decade of EU Migration AND Asylum Law 47, 69 (Elspeth Guild \& Paul Minderhoud eds., 2012); For case-law, see e.g., Case C-158/07, Förster v. Hoofddirectie van de Informatie Beheer Groep, 2008 E.C.R. I-08507; Case C-224/98, D’Hoop v. Office national de l'emploi, 2002 E.C.R. I-06191; Case C-138/02, Collins v. Sec'y of State for Work \& Pensions, 2004 ECR 2 I-02703; Case C-103/08, Gottwald v. Bezirkshauptmannschaft Bregenz, 2009 E.C.R. I-09117; Joined Cases 523/11 \& 85/11, Laurence Prinz v. Region Hannover and Philipp Seeberger v. Studentenwerk Heidelberg, 2013 EUR-Lex CELEX LEXIS 524 (July 18, 2013).

${ }^{26}$ This discussion is indeed very relevant for the determination of human rights-based obligations. As the European Court of Human Rights put it, "the exercise of jurisdiction is a necessary condition for a Contracting State to be able to be held responsible for acts or omissions imputable to it which give rise to an allegation of the infringement of rights and freedoms set forth in the Convention.” Al-Skeini \& Others v. United Kingdom, 2010 Eur. H.R. 55721/07. In most cases, territorial borders and jurisdictional borders fall together. This presumption is also accepted by the European Court of Human Rights see Hirsi Jamaa \& Others v. Italy, 2012 Eur. H.R. 27765/09. Nevertheless, as a series of highly sensitive cases has shown, this is not necessarily the case. E.g. 40/1993/435/514, Loizidou v. Turkey Rep. 1996-VI Eur. H.R.; Bankovic v. Belgium \& Others, 2001-XII Eur. H.R. 52207/99; Al-Saadoon v. United Kingdom, 2010 Eur. H.R. 61498/08; Al-Skeini \& Others v. United Kingdom, 2010 Eur. H.R. 55721/07; Medvedyev v. France, 2010 Eur. H.R. 3394/03; Hirsi Jamaa \& Others v. Italy, 2012 Eur. H.R. 27765/09.

${ }^{27}$ Ana Besson, An Empty Shell? The Protection of Social Rights of Third-Country Workers in the after the Single Permit Directive, 25 LEIDEN J. OF INT'L L. 857, 860 (2012).

${ }^{28} I d$. at 872 .

${ }^{29}$ For a general introduction, see Bernard Ryan \& VAlsAmis Mitsilegas, EXtraterritorial Immigration Control: Legal Challenges (Nartinus Nijhoff Publishers, 2010). See also Cathyrn Costello, The Asylum Procedures Directive in Context: Equivocal Standards Meet General Principles, in Whose Freedom, Security and Justice? EU Immigration And Asylum Law and Policy 287, 295 (Anneliesse Baldaccini, et al. eds., 2012).

${ }^{30}$ For a comprehensive treatment of this issue, see MAARTEN Heijer, Europe AND Extraterritorial Asylum (Hart Publishing, 2012).
} 
the power of a public authority, as in the example of Italian coast guards intercepting boats in international waters. $^{31}$

What can we learn from this definition of jurisdiction for the case of our IT specialist submitting an application to immigrate to the EU? Although the potential immigrant might still be in his country of origin, his application to be admitted as a Blue Card holder should be considered within the jurisdiction of the EU. ${ }^{32}$ Notwithstanding the issue of his specific entitlements or prerogatives for the time being, this potential immigrant shares a jurisdictionally relevant link to the EU. Drawing upon the conception of jurisdiction proposed by Besson, the authority of the EU is, in this situation, clearly not only a token of mere coercion. By applying the EU legal regime on immigration, public authorities — which might be national bodies applying EU law-claim political and legal authority, most importantly, by providing a normative framework on how and for which reasons the application should be denied or accepted. ${ }^{33}$ In general, this implies that the application is to be assessed and decided upon as an EU-internal matter and according to the relevant EU legal norms - and national relevant norms. ${ }^{34}$

In the end, there is a distinction to be made between a potential immigrant who is not under the jurisdiction of the EU and his application being under this jurisdiction. Making this distinction allows us to distinguish the case of the IT specialist from the case of asylum seekers trapped on a boat intercepted by Frontex. ${ }^{35}$ The IT specialist himself is not under the jurisdictional ambit of the EU, only his application is. In contrast, the asylum seeker is himself in a relation with an EU public authority, which might certainly be argued to trigger the threshold of jurisdiction as defined above. ${ }^{36}$

This brief discussion aims at clarifying the theoretical background of the jurisdictional link between a potential immigrant submitting an application and a public authority. This application creates a relevant relation between a public authority and an individual. This relation is concretized through a specific legal procedure-and a decision-established by a public authority acting in accordance with EU law.

\section{Applicability of qua general principles in EU law}

Given this general theoretical background, the second dimension of applicability focuses on the applicability of proportionality qua general principle of EU law. In EU law, general principles of law are applicable under the condition that the measure or decision be "within the scope of the Treaties." In brief, our hypothesis is that the majority of labor immigration applications should be considered to fall within the scope of EU law and therefore the general principle of proportionality is applicable to this majority of applications. ${ }^{37}$

The applicability of general principles reflects the exercise of the general competence on immigration given to the EU by the Member States. Several immigration-related Directives were already enacted by the Union legislator and represent legal venues upon which general principles are clearly applicable. To a different extent, the Blue Card Directive and the other sectorial

\footnotetext{
${ }^{31}$ See Hirsi Jamaa \& Others v. Italy, 2012 Eur. H.R. 27765/09.

${ }^{32}$ To make the link to the ethical literature on migration, this framing seems to be similar to the one proposed by Miller, see David Miller, Border Regimes and Human Rights, 7 L \& ETHICs OF Hum. RTs. 1, 4 (2012).

${ }^{33}$ See Besson, supra note 27, at 865 . As Besson writes, "It amounts to more than the mere exercise of coercion or power as a result: it also includes a normative dimension by reference to the imposition of reasons for action on its subjects and the corresponding appeal for compliance (e.g., through giving instructions).”

${ }^{34}$ For this point, see Bast, supra note 3, at 1021-24.

${ }^{35}$ Exactly this distinction seems to be overlooked by Blake writing that a prospective migrant submits "one's self to the coercive authority of a state for purposes of admission." See Michael Blake, Immigration and Policitcal Equality, 45 SAN Diego L. Rev. 963, 965 (2008).

${ }^{36}$ Sylvie Sarolea, La souveraineté en droit belge: mythe et réalité, in L'ÉTRANGER FACE AU DROIT: XXES JOURNÉES D'ÉTUDES JURIDIQUES JEAN DABIN 93 (Jean-Yves Carlier ed., 2010).

${ }^{37}$ This question shares important elements with the question of applicability of the Charter (for example mainly the interpretation of its Art. 51). We shall come back to this later.
} 
Directives constitute a legally relevant position for TCNs wanting to enter the EU by granting them relatively strong entitlements. The same applies to the issue of family reunification. ${ }^{38}$ Overall, these Directives represent clear cases in which EU law is applicable to the first admission of TCNs. Beyond these Directives, EU law might ensure a TCN a right or privileged treatment through a specific international agreement. ${ }^{39}$ Overall, the applicability of general principles of law is a function of the Europeanization of the field of immigration. ${ }^{40}$

In addition to these cases in which the applicability of general principles is not disputed, my hypothesis is to contend that the Single Permit Directive ${ }^{41}$ might be considered a very significant EU legislative act in terms of bringing an important number of cases within the scope of EU law. ${ }^{42}$ As put by Bast in addressing the applicability of procedural rights, "even a rather 'shallow' harmonization of laws can have a 'deep' impact on national legal order since the legislative act has the effect of bringing the matter within the scope of EU law." 43

We shall proceed by focusing on the core prescriptions of the Single Permit Directive for the Member States, namely the obligation to create a single application procedure to issue single permits for TCNs to reside for work purposes. The Directive calls upon Member States to establish "a more efficient procedure both for the migrants and for their employers" and "easier controls of the legality of their residence and employment" (Recital 3). Article 4(1) of the Directive calls upon the Member States to put into place a single permit procedure through which potential labor immigrants might apply for residence and work permit simultaneously. Article 4(2) calls upon the Member States to "examine an application made under paragraph (1)" and "adopt a decision to issue, amend or renew the single permit if the applicant fulfills the requirements specified by Union or national law." This Union or national law is not part of this Directive. The Directive does not foresee any specific material criteria regarding application assessment.

Furthermore, the personal scope of the Directive is fairly limited, as an important number of immigration categories have been excluded. Nevertheless, the fact that numerous categories are excluded does not invalidate the relevance of the Single Permit Directive for matters of labor immigration. As put by de Lange, the following categories remain within the scope of the Directive: "TCN Students when employed and researchers, Blue Cards and most migrating workers coming in through other national schemes as well as family members of nationals and family members who came in under the Family reunification Directive." ${ }^{44}$ As Peers wrote in 2012, "from mid-2011, some proportion of the migrants admitted for employment (24\% of the total in 2009) have fallen within the scope of the Blue Card Directive, and from Christmas Day 2013, most of the remaining applications for labor migration will fall within the scope of the Single Permit Directive." ${ }^{35}$

\footnotetext{
${ }^{38}$ Johan Rochel, Immigration to the EU: Challenging the Normative Foundations of the EU Immigration REGIME 158 (Schulthess, 2015).

${ }^{39}$ See Evelien Brouwer, Effective Remedies for Third Country Nationals in EU Law: Justice Accessible to All?, in The First Decade of EU Migration and Asylum Law 375, 383-85 (Elspeth Guild \& Paul Minderhoud eds., 2012); Case C-327/02, Lili Georgieva Panayotova \& Others v. Minister voor Vreemdelingenzaken en Integratie, 2004 E.C.R. I-11055.

${ }^{40}$ In that context, Bast speaks of "normalisation" of immigration law through its Europeanization. See Bast, supra note 7, at 293-294.

${ }^{41}$ Directive 2011/98, supra note 8.

${ }^{42}$ See Kees Groenendijk, Equal Treatment of Workers from Third Countries: The Added Value of the Single Permit Directive, 16 ERA Forum 547 (2015); Yves Pascouau \& Sheena McLoughlin, EU Single Permit Directive: a Small Step Forward in EU Migration Policy, European Policy Center 1, 3-4 (2012), http://www.epc.eu/documents/uploads/pub_1398_eu_single_ permit_directive.pdf?doc_id=1207 (Interestingly, Pascouau \& McLoughlin do not mention the importance of the Charter and the general principles).

${ }^{43}$ Bast, supra note 3, at 1020 .

${ }^{44}$ Tesseltje De Lange, The Single Permit Directive: A Limited Scope, a Simple Procedure and Limited Good Administration Requirements, in The Single Permit Directive: Central Themes and Problem Issues 5, 7 (Paul Minderhoud \& Tineke Strik eds., 2015).

${ }^{45}$ Steve Peers, An EU Immigration Code: Towards a Common Immigration Policy, 14 EuR. J. Of MigRATION \& L. 33, 27 (2012).
} 
While the limited literature on the Single Permit Directive has focused mainly on Article 12 of the Directive-equality ${ }^{46}$ - the present Article addresses a meta-dimension pertaining to the applicability of general principles. By transposing the Directive and creating the required procedure, Member States are clearly implementing EU law. More specifically, by following the categorization proposed by Lenaerts, Member States are fulfilling an obligation prescribed by EU law. ${ }^{47}$ If this strong link is established between EU law, the Directive as implementation of the general immigration competence entailed by the TFEU, and the obligation prescribed to the Member States-the procedure-the procedure shall clearly be considered within the scope of EU law. ${ }^{48}$

Continuing this analysis, the CJEU made it clear in N.S. that Member States might enjoy certain discretion as an integral part of EU law but that, as a consequence, the exercise of this discretion was to be considered a form of implementation of EU law. In this specific case, the CJEU decided on the so-called sovereign discretion clause - which the Member States might claim was part of the normative scheme put into place by EU law_-and that, consequently, the Charter was applicable. ${ }^{49}$ This argument could be extended by integrating a link to the broad policy pursued by the $\mathrm{EU}^{50}$ or the effectiveness of the interests it protects. ${ }^{51}$ In Rottman, the general principle of proportionality was applied to the competences retained by the Member States - on access to nationality-if a link could be established with EU law. ${ }^{52}$ This would entail an extension of the argument proposed above, meaning that larger parts of the relevant norms would fall within the scope of EU law.

By analogy, the argument proposed with respect to the Single Permit Directive can be compared to the Asylum Procedures Directive. ${ }^{53}$ Clearly, the Asylum Directive regulates in more detail the core elements of the procedure to be applied by the Member States. ${ }^{54}$ In comparison, the Single Permit Directive entails only some general prescriptions about procedural guaranteesArticle 8. But for our argument, it is, above all, important to highlight the fact that the procedure itself is prescribed as a matter of EU law and that, consequentially, general principles of EU law apply to it. ${ }^{55}$ Proportionality qua general principle is hence applicable to the procedure created by the Single Permit Directive.

\footnotetext{
${ }^{46}$ See Paul Minderhoud \& Tineke Strik, The Single Permit Directive: Central Themes and Problem Issues (Wolf Legal Publishers, 2015). On social rights, see Ana Beduschi, An Empty Shell? The Protection of Social Rights of Third-Country Workers in the EU after the Single Permit Directive, 17 EUR. J. OF Migration AND L. 210 (2015). For case-law, Case C-449/16, Kerly Del Rosario Martinez Silva v. Istituto nazionale della previdenza sociale (INPS) \& Comune di Genova, 2017 EUR-Lex CELEX LEXIS 485 (June 21, 2017).

${ }^{47}$ Koen Lenaerts, Exploring the Limits of the EU Charter of Fundamental Rights, 8 Eur. Const. L. REv. 375, 378 (2012).

${ }^{48} \mathrm{By}$ analogy, and the same discussion on the asylum procedure see Joined Cases 411/10 \& 493/10, N. S. v. Sec'y of State for the Home Dep't \& M. E. \& Others v. Refugee Applications Comm'r \& Minister for Justice, Equality \& Law Reform 2011 E.C.R. I-13905; See also, Marcelle Reneman, EU Asylum Procedures and the Right to an Effective Remedy 390 (Hart Publishing, 2014).

${ }^{49}$ Joined Cases 411/10 and 493/10, supra note 48; For further case-law where the Charter was considered to apply, see Case C-279/09, DEB Deutsche Energiehandels-und Beratungsgesellschaft mbH v. Bundesrepublik Deutschland 2010 E.C.R. I-13849; Case C-40/11, Iida v. Stadt Ulm, 2012 EUR-Lex CELEX LEXIS 691 (Nov. 8, 2012); Case C-400/10, J. McB. V. L. E., 2010 E.C.R.; See generally Koen Lenaerts, Exploring the Limits of the EU Charter of Fundamental Rights, 8 EUR. CONST. L. REV. 375,385 (2012).

${ }^{50}$ Joined cases 286/94, 340/95, 401/95, \& C-47/96, Garage Molenheide BVBA, Peter Schepens, Bureau Rik Decan-Business Research \& Development NV (BRD) \& Sanders BVBA v. Belgische Staat 1997 E.C.R. I-07281.

${ }^{51}$ Case C-207/86, Asociación Profesional de Empresarios de Pesca Comunitarios (Apesco) v. Comm'n of the European Communities, 1988 E.C.R. 2151.

${ }^{52}$ Case C-135/08, Rottmann v. Freistaat Bayern, 2010 E.C.R. I-01449.

${ }^{53}$ Directive 2013/32, of the European Parliament and of the Council of 26 June 2013 on Common Procedures for Granting and Withdrawing International Protection, 2013 O.J. (L 180).

${ }^{54}$ See Marcelle Reneman, EU Asylum Procedures and the Right to an Effective Remedy 390 (Hart Publishing, 2014); Herwig Verschueren, Access to an Effective Remedy before a Court or Tribunal in Asylum Cases in THE FIRST DECADE OF EU Migration and Asylum Law 401 (Elspeth Guild \& Paul Minderhoud eds., 2012).

${ }^{55}$ By analogy, see the argument advanced by Cathyrn Costello, Courting Access to Asylum in Europe: Recent Supranational Jurisprudence Explored, 12 Human Rights L. REV. 287, 307 (2012); Costello, supra note 1, at 180; see also Ryszard
} 


\section{Applicability of proportionality to protected interests}

The third dimension deals with applicability to the specific situation of the admission application. It might be argued that proportionality does not apply where there is no legally protected right. Therefore, the applicability of proportionality would have the prerequisite of an existence of something like a right to immigrate to which infringement proportionality would apply.

As we address this important point, let us again take our example of the Indian IT specialist applying for a Blue Card permit — through a procedure foreseen by the Single Permit Directive. EU law has created a legal position for him by laying out the conditions that need to be fulfilled, the administrative steps to submit an application, and references to potential grounds for refusal as set in national or Union law. As formulated by Bast, the activity of the Union legislator has created "an entitlement to a legal status" for TCNs. ${ }^{56}$ There is no entitlement to be admitted into the EU-in contrast to specific situations of family reunification ${ }^{57}$ - but there is an entitlement to be treated in a just and fair way with regards to the applied procedure. If the Union legislator creates a legal channel for immigration and describes the conditions of its access, this channel, and the decision taken through it, becomes inseparable from the principles to which this public authority is committed. As put by Schotel, the point is not about the recognition a free movement for potential immigrants, "but the adequate administration of the law." 58 The key interest at stake is therefore the interest of being adequately handled by a public authority in a procedure, which was created by this public authority.

The connection with the good administration of the law becomes clearly visible in the case of the Single Permit Directive. The Directive is about laying down the procedure through which an application should be handled. As stated in Recital 5,

a set of rules governing the procedure for the examination of single permit applications should be laid down. That procedure should be effective and manageable, should take into account the normal workload of the Member States' administrations, as well as be transparent and fair, in order to offer appropriate legal certainty to those concerned.

This last point is essential, the Directive creates a legal entitlement for potential immigrants applying for a permit: "Those concerned" should be treated fairly.

In Article 8, the Single Permit Directive lists a number of procedural guarantees which broadly reflect the right to good administration as entailed by the Charter, which in turn has formalized the case law developed by the CJEU on this issue - thanks to the vehicle of general principles and the upgrading of procedural guarantees as fundamental rights. ${ }^{59}$ The right to good administration is about "the right to have one's affairs handled impartially, fairly and within a reasonable time by the institutions and bodies of the Union." ${ }^{60}$ In the second paragraph of Article 41 of the Charter, three specific rights are highlighted: The right to be heard, the right to access one's file, and the

Cholewinski, The Need for Effective Individual Legal Protection in Immigration Matters, 7 EUR. J. OF MigRATION AND L. 237, 259-62 (2005); for the example of the right to an effective judicial review, see Case C-69/10, Brahim Samba Diouf v. Ministre du Travail, de l'Emploi et de l'Immigration, 2011 E.C.R. I-07151.

${ }^{56}$ Bast, supra note 3, at 1023 .

${ }^{57} \mathrm{Or}$ in the continuation of the case-law by the CJEU on the "exhaustiveness" of the conditions of entry laid down in secondary law on immigration to the EU. For the Students Directive see Case C-491/13, supra note 10.

${ }^{58}$ Bas Schotel, On the Right of Exclusion: Law, Ethics and Immigration Policy 192 (London: Routledge, 2012).

${ }^{59}$ On this development, see Bast, supra note 3, at 1015. For case-law, see Joined cases 204/00 P, 205/00 P, 211/00 P, 213/00 P, 217/00 P \& 219/00 P, Aalborg Portland A/S, Irish Cement Ltd, Ciments français SA, Italcementi - Fabbriche Riunite Cemento SpA, Buzzi Unicem SpA \& Cementir - Cementerie del Tirreno SpA v. Comm'n of the European Communities, 2004 E.C.R. I-00123.

${ }^{60}$ U.N. Charter art 41; For early comments on this development in EU law, see Klara Kanska, Towards Administrative Human Rights in the EU. Impact of the Charter of Fundamental Rights, 10 EUR. L. J. 296 (2004); Jane Reichel, Between Supremacy and Autonomy - Applying the Principle of Good Administration in the Member States, in GENERAL PRINCIPLES of EC Law in a Process of Development 243 (Ulf Bernitz, et al. eds., 2008). 
obligation by the administration to give reasons for its decisions. The procedural guarantees foreseen by the Single Permit Directive directly echo these elements. ${ }^{61}$

An important stream of literature has focused on the issue of the applicability of Article 41 -as a derogation from the general rule foreseen by Article 51 of the Charter. The present Article does not need to claim that the right to good administration as entailed by the Charter is applicable, thereby taking position on the issue of the scope of Article 41 in immigration cases. After several somewhat unclear decisions, the CJEU ruled that Article 41 is addressed, not to the Member States, but solely to the institutions, bodies, offices, and agencies of the European Union. ${ }^{62}$ Nevertheless, in a subsequent decision, the Court specified the relationship between good administration as right of the Charter-with restricted applicability — and as general principle of EU law. It thereby clearly stated that the right to good administration was "inherent in respect to the rights of the defense, which is a general principle of EU law." ${ }^{63}$ For the present argument, the applicability of Article 41 would indeed make the argument stronger, but what is necessary is the applicability of its content through the vehicle of the general principle. ${ }^{64}$ It is through the effect of the general principle on the interpretation of the procedural rules foreseen by the Single Permit Directive that the ratio legis of good administration is playing its role. ${ }^{65}$

To close this preliminary reflection on the third dimension of applicability, my argument has highlighted the link between the existence of an EU-law procedure-and the procedural interests inherent to it-and the applicability of general principles, such as proportionality. The interests created by the Single Permit Directive are procedural in nature and they reflect the bundle of guarantees entailed by the principle of good administration. In other words, the argument does not rely upon a putative right or protected interest to immigrate, but rather upon "the adequate administration of the law" with respect to the interests that have been created, affected, and, at the same time, protected by specific legal norms of the Single Permit Directive. ${ }^{66}$ The argument is, therefore, that the principle of proportionality applies to the specific interests created by the existence of a legal channel of immigration. It is simultaneously its strength-the solid tradition of protecting these procedural interests - and its limitation-no substantial interest outlining something like a right to immigrate.

To sharpen the argument ${ }^{67}$ imagine the opposite case of someone wanting to immigrate to the EU without having any legal channel available. In this case, there are no protected interests to which we should apply proportionality; EU law does not create any legal position to the potential immigrant. To put it plainly, there is no procedure available to lodge an application. There is no doubt that some de facto interests of potential immigrants are affected-arguably even de facto interests with a high moral value, but these are not legally protected, because the potential immigrant was not given any legal position. ${ }^{68}$

\footnotetext{
${ }^{61}$ Tesseltje De Lange, The Single Permit Directive: A Limited Scope, a Simple Procedure and Limited Good Administration Requirements, in The Single Permit Directive: Central Themes and Problem Issues 5, 11 (Paul Minderhoud \& Tineke Strik eds., 2015).

${ }^{62}$ Joined Cases 141/12 and 372/12, YS v. Minister voor Immigratie, Integratie en Asiel and Minister voor Immigratie, Integratie en Asiel v. M \& S, 2014 EUR-Lex CELEX LEXIS 2081 (July 17, 2014).

${ }^{63}$ Case C-166/13, Sophie Mukarubega v. Préfet de police \& Préfet de la Seine-Saint-Denis, 2014 EUR-Lex CELEX LEXIS 2336 (Nov. 5, 2014); On this double focal, Case C-604/12, H.N. v. Minister for Justice, Equality \& Law Reform and Others, 2014 EUR-Lex CELEX LEXIS 302 (May 8, 2014) (general principle of good administration and its counterpart in the Charter). Similarly, on the right to be heard as general principle and as right in the Charter, see Case xC-277/11, M. M. v. Minister for Justice, Equal. and Law Reform, Ireland \& Attorney General, 2012 EUR-Lex CELEX LEXIS 744 (Nov. 22, 2012).

${ }^{64}$ This point does not address the-maybe distinct-degree of protection guaranteed by these two norms. On this, see Krisztian Kecsmar, Arrêt Mukarubega: Droit à une bonne administration à deux vitesses?, 597 REVUE DE L'UNION EUROPÉENNE 239 (2016).

${ }^{65}$ Marcelle Reneman, EU Asylum Procedures and the Right to an Effective Remedy 94-98 (Hart Publishing, 2014).

${ }^{66}$ Schotel, supra note 58 , at 192.

${ }^{67}$ This strategy is borrowed from Bast, supra note 3, at 1023.

${ }^{68}$ For this point see Schotel, supra note 58, at 190.
} 


\section{Intermediary conclusions}

Three dimensions of the issue of applicability were addressed. First, an application for admission, for example the submission of a Blue Card application through a Single Permit procedure creates a jurisdictionally relevant link and therefore, the public authority is under the obligation to respect its own standards - for example with respect to procedural guarantees. Second, these standards qua general principles of EU law are applicable. In the course of the Europeanization of immigration law-not least due to the Single Permit Directive-the majority of applications regarding labor immigration fall within the scope of the Treaties and general principles are hence applicable. Similar reflections apply to the applicability of the Charter. Third, proportionality is applicable to cases in which EU law creates a legal position for potential immigrants. Once a legal channel is created, the EU has to respect its own principles in dealing with applications lodged through this channel. Proportionality is hence applicable to the specific interests created by the existence of an EU-law procedure.

\section{The normative pressure of proportionality}

In this chapter, the focus is shifted from the applicability of the general principle of proportionality to the identification of the consequences which its application might bring about. My main objective is to investigate the application of proportionality to the procedural interests created by the Single Permit Directive and in doing so, highlight the normative pressure which proportionality might exercise. As previously explained, the focus is on the joint application of procedural guarantees - as general principles, and as anchored in the Charter-and the general principle of proportionality. To take the example of the IT specialist, the point is to draw upon proportionality in conjunction with key procedural guarantees to challenge the quality of the decision delivered by the EU acting as public authority or by national authorities applying EU law. My point is not to claim that the substance of the decision on the application should be challenged in light of proportionality - the approval or denial of a residence and work permit. It is only the quality of the reasons given to the applicant through the procedure which should be challenged. Neither do I need to defend the potential idea that procedural guarantees are emanations of proportionality. It might of course be historically and conceptually cogent to derive procedural guarantees from proportionality. ${ }^{69}$ On one hand, procedural guarantees now have a strong and independent legal position-qua general principle and qua Article 41 Charter. On the other hand, my argument focuses on a joint application of proportionality and on the procedural guarantees.

In order to demonstrate the potential of this argument, I focus on one of the most important interests created by an immigration-related procedure, namely the right to be informed of the reasons given by the authority to justify its decision: In brief, the right to a reasoned decision. As I shall argue in conclusion, my argument works analogously with the other components of the bundle of procedural guarantees entailed by the good administration of the law. ${ }^{70}$

My hypothesis is that two types of consequences are especially interesting. The first is a general consequence about proportionality creating a normative space to identify interests and exchange arguments. The second is specific to the right to reasoned decision on the identification and evaluation of the empirical considerations of the decision. Altogether, these two elements illustrate how proportionality might be mobilized to exercise a pressure towards better decisions. The argument will reveal a more theoretical contribution to the relevance of proportionality as a normative

\footnotetext{
${ }^{69}$ On this point, see Sacha Prechal, Free Movement and Procedural Requirements: Proportionality Reconsidered, 35 LEGAL IsSUES OF ECON. INTEGRATION 201 (2008); In the philosophy of law-with a focus on fundamental rights, see Robert Alexy, Constitutional Rights and Proportionality, 22 RevUs 2 (2014).

${ }^{70}$ See Bast, supra note 3 (discussing the right to be heard).
} 
device protecting individual freedom and setting limits to a certain understanding of discretion in immigration matters.

\section{The right to reasoned decision}

As a matter of EU law, the right to reasoned decision is to be interpreted against the background of the general obligation for the EU to support all legal acts with reason. ${ }^{71}$ In this very broad sense, this right - respectively this obligation for the public authority ${ }^{72}$ - is an emanation of the general principle of legality. More specifically, the right to a reasoned decision has been conceived as an essential component of the right to an effective judicial remedy. ${ }^{73}$ It is inherently linked to the idea that the affected person should be fully informed on the reasoning followed by the public authority in order to be able to defend himself or herself. As defined by the CJEU, the duty to provide reasons entails the following:

The statement of reasons must disclose in a clear and unequivocal fashion the reasoning followed by the Community authority which adopted the measure in question, in such a way as to make the persons concerned aware of the reasons for the measure and thus enable them to defend their rights and to enable the Court to exercise its supervisory jurisdiction. ${ }^{74}$

This right includes at least two essential elements: To be informed of the legal basis of the decision taken and the legal reasoning followed by the administrative or judicial body. ${ }^{75}$

Going one step further, the general rationale followed in EU law might be unpacked in two related claims. On the one hand, the right to a reasoned decision is an important element in the judicial review of a specific measure. For example, in a case of a court assessing a specific measure, the capacity to exactly know the legal basis and the reasoning followed by the administrative or judicial body enacting the decision is of crucial relevance in order to review its legality. On the other hand-but strongly linked to this first dimension - the right to a reasoned decision is part of the bundle of elements required by an affected person for the assessment of his or her legal case. In this perspective, the main objective is to force the public authority to interact transparently with the affected person in order to secure this person enough information to be able to understand, reconstruct, and perhaps contest a decision. The right to a reasoned decision ensures that legal relations between a public authority and the affected persons and entities remain foreseeable and predictable. It requires the public authority to be able to justify its decisions in the form of reasons that are understandable for the affected person. By getting notified about the reasons, the affected person or entity is in a position to ascertain his or her legal position and the associated rights and obligations. From a general point of view, the law and its application appear transparent, understandable, and hence legitimate.

Assuming the framing proposed by Mashaw, these two related dimensions might be considered the two main elements of an instrumental view on the right to reasoned decision. According to Mashaw, this view is instrumental in conceiving the right to reasoned decision as to serve further

\footnotetext{
${ }^{71}$ TFEU art. 296; Catherine Barnard \& Steve Peers, European Union Law 216 (Oxford University Press, 2014).

${ }^{72}$ Note that U.N. Charter Art. 41 speaks of a right, while the TFEU considers the duty. On this, see Ingrid Opdebeek \& Stephanie De Somer, The Duty to Give Reasons in the European Legal Area: A Mechanism for Transparent and Accountable Administrative Decision-Making? A Comparison of Belgian, Dutch, French and EU Administrative Law, 2 RocZNIK Administracji PublicZnej 97, 101 (2016).

${ }^{73}$ Jane Reichel, Between Supremacy and Autonomy - Applying the Principle of Good Administration in the Member States, in General Principles of EC Law in a Process of Development 243, 251 (Ulf Bernitz, et al. eds., 2008).

${ }^{74}$ Case C-269/90, Technische Universität München v. Hauptzollamt München-Mitte, 1991 E.C.R. 199105469.

${ }^{75}$ See Juergan Schwarze, European Administrative Law 1400 (Sweet and Maxwell, 2006); Paul Craig, EU Administrative Law 340 (Oxford University Press, 2012).
} 
important objectives, such as the right to defense and the good functioning of judicial review. ${ }^{76}$ The right to a reasoned decision is a means for broader purposes. As he explains, this instrumental view might well account for the incremental development of this procedural guarantee. In that sense, it might well echo the development of the general principle of EU law, ${ }^{77}$ focusing on the role played by the right to reasoned decision in the broader construct of a functioning and just EU legal order.

Nevertheless, Mashaw proposes to further deepen this instrumental view and account for the right to a reasoned decision against the background of a certain view about the person as a human being and the legitimate claim associated to this status. He labels this view as "Aristotelian." In this second view, there is a strong argument for the right to a reasoned decision in drawing upon the status of the human being as a rational being with a strong claim to be handled as an end in himself or herself, and not merely as an object or an instrument for broader purposes. Following that argument, a public authority interacting with a human person is under the obligation to consider this individual as a person with a claim to be treated as reasons-bearer, namely as a person to whom reasons are owed. As Mashaw puts it, "authority without reason is literally dehumanizing." ${ }^{\text {" }}$ A justification in the form of reasons is owed to individuals with whom the public authority interacts. This claim about the personhood and related claims might indeed be further enriched, but for the purpose of this Article, the main idea should be sufficient. ${ }^{79}$ This is of course especially true for a public authority such as the EU, which is committed to values such as freedom and equality and whose legitimacy relies upon the respect of these fundamental values. Although the present argument does not depend upon this claim, it might be argued that this second "Aristotelian" account of the right to a reasoned decision relates more clearly to its understanding as a subjective fundamental right—-such as entailed by the Charter as part of the right to good administration. This right is not only exclusively there for the purpose of securing other purposes or objectives, but because it is important per se that persons should be taken seriously and given reasons when they are affected by a public authority.

Although the practical consequences of the distinction between the instrumental and personhood-based-Aristotelian-views of the right to a reasoned decision might not be overwhelming at first glance, the distinction is important when it comes to the joint application with proportionality. The right to a reasoned decision applied in conjunction with proportionality raises a main question: In the justification given to the affected person, which type of quality can be expected from the point of view of the good administration of the law? Expressed in the structure of the principle of proportionality, which quality of justification is suitable, necessary, and fulfills proportionality s.s.? Or in other words, which quality of justification would be appropriate to attain the objective pursued and would not go beyond what is necessary to achieve it?

It quickly appears that the issue of the broader framing mentioned earlier is looming large when trying to specify this joint application of a reasoned decision and proportionality. More specifically, it is namely the final purpose of the right to reasoned decision that is relevant as part of the right to defense and judicial review or, more deeply, as a duty towards personhood. On one side, if conceived instrumentally as an element of the right to defense, the question of proportionality should be asked in the following way: Which quality of justification is suitable, necessary, and consistent with proportionality s.s. in order to enable an affected person to defend himself in

\footnotetext{
${ }^{76}$ Jerry L Mashaw, Reasoned Administration: The European Union, the United States, and the Project of Democratic Governance, in YAle FACULTY SCHOLARSHIP SERIES 1179 99, 101 (2007).

${ }^{77}$ E.g. Case C-222/86, Union nationale des entraîneurs et cadres techniques professionnels du football (Unectef) v. Heylens and others, 1987 E.C.R. 4097.

${ }^{78}$ Mashaw, supra note 76, at 118.

${ }^{79}$ In this respect, there seems to exist an interesting link to the human rights literature and the issue of their foundation. For reflections in this direction, see JAMES GRIFFIn, ON HuMAN Rights (Oxford University Press, 2008); Rainer Forst, The Justification of Human Rights and the Basic Right to Justification: A Reflexive Approach, 120 ETHICs 711 (2010).
} 
a satisfactory way and to enable an efficient judicial review? This question immediately raises a set of questions as to the legitimate expectations one could have with regard to the right to defense and what is due in terms of leveling the playing field between the public authority and the affected persons. On the other side, if the right to a reasoned decision is conceived as a subjective right linked to personhood, the main question to raise appears to be slightly different: Which quality of justification is suitable, necessary, and consistent with proportionality s.s. in order to make a decision enacted by a public authority that is compatible with the respect due to human persons? According to this framing, the main issue is the legitimate expectations of an individual who is affected by a decision taken by public authority. In one extreme case, the public authority might be expected to justify every possible point-for example to provide detailed information on the elements at stake. This might indeed be possible in theory, but as practical administrative matters, justifications have to find a difficult balance between being too lapidary and covering every possible argument and counterargument.

There is one important lesson learned: The general conception in which the conceived right to reasoned decisions is important when outlining how joint application with the principle of proportionality will look like. The underlying conception will have practical consequences when applied in specific cases. This does not prevent the two principles from being jointly applied before solving every problematic issue of this complex relation.

\section{Proportionality in action}

Assuming the precedent reflections on the right to a reasoned decision, we can now turn to the task of identifying potential consequences of the joint application with the principle of proportionality in the case of the Single Permit Directive. I make a distinction between a general consequence and a more specific argument on the empirical considerations that sustain a specific decision.

First, it is important to highlight the general consequence of applying proportionality: It creates a normative space to identify and assess distinct interests. Following Franck, the idea is to conceive a proportionality assessment as a normative space in which "the terms in which the parties to a dispute advance their self-justification" are laid down. ${ }^{80}$ As put by Stone Sweet and Mathews, this means that proportionality is accounted as a procedure creating an "argumentation framework." 11 In our case, this is the space in which the public authority is called to assess the way it interacts with affected individuals and, more specifically, the type of justification which is owed to this person. Franck stresses this function when he writes that the role of proportionality is not to "prevent bad decisions but to create optimum opportunity for good ones by creating a space to render transparent, principled second opinions." 82

In this respect-as noted by Lecucq-proportionality has an interesting "unveiling" function when it comes to the determination of the interests that ought to be protected from public authority interferences. ${ }^{83}$ In brief, the necessity to conduct a proportionality assessment requires the public authority to identify which interests are at stake. Lecucq distinguishes a negative from a positive "unveiling" function. The negative dimension focuses on the fact that a test of proportionality requires a relatively precise identification of the interests at stake. In other words,

\footnotetext{
${ }^{80}$ Thomas Franck, On Proportionality of Countermeasures in International Law, 102 AM. J. OF INT'L L. 715, 715-16 (2008).

${ }^{81}$ Alec Stone Sweet \& Jud Mathews, Proportionality Balancing and Global Constitutionalism, 47 COLUM. J. INT'L L. 73, 88 (2008).

${ }^{82}$ See Franck, supra note 80 , at 755.

${ }^{83}$ Olivier Lecucq, Le principe de proportionnalité: Simple technique juridictionnelle ou norme de fond. Réflexions tirées du droit constitutionnel des étrangers, 8 CONGRÉ MONDIAL DE L'AsSOCIATION INTERNATIONALE DE DROIT CONSTITUTIONNEL 1 , 6-7 (2010).
} 
proportionality makes the protected interests clearly visible. In the positive dimension, to declare a decision non-proportionate indicates that a limit to public authority has been transgressed. The focus has shifted from the identification of the interests to the limits placed over them.

Applied to the right to a reasoned decision, a proportionality assessment would require the public authority to identify the relevant information to be delivered in order to reach a sufficient threshold of quality in the justification. This task presupposes a mapping of the different interests at stake - on the side of the public authority and on the side of the affected person. The negative "unveiling" function highlights our former discussion on the underlying framing of the right to a reasoned decision from a new perspective. It creates the normative space in which to develop a common understanding of which the quality of justification should be expected from a public authority like the EU. As a consequence, it is the space in which the underlying framings identified above should be discussed. Proportionality does not furnish a clear-cut answer as to which of the two framings identified is the best, but it creates the normative space to have this debate.

Where to start? As noted by Schotel, we should take benefit from the dynamic nature of proportionality. There is no requirement to present a full-fletched theory of proportionality in conjunction with the right to reasoned decision, but rather to get a movement started and allow an incremental approach to be developed. This shall first occur "at the extremes" by applying higher standards of justification to some very specific cases, thereby allowing the first pieces of a theory of proportionate justification given to applicants in first-admission cases to be laid down. ${ }^{84}$ We shall discuss potential examples below.

Second, to make this general consequence more tangible, the joint application might be focused on providing an argument to improve the quality of the justification given on an important point - namely the identification of empirical elements in a specific decision. In brief, proportionality is used to exercise pressure on the public authority to go further than a lapidary justification mentioning legal sources and quickly summing up the reasoning followed. The objective is to challenge the justification presented by the public authority on the quantity and quality of identified empirical considerations and delivered as part of the decision. In the perspective of securing the best possible quality of the administration of the law, the point here is to ask in which way proportionality could be used as a lever to exercise a pressure towards better decisions, being better defined on two counts: As more comprehensive in the availability of the reasons justifying specific decisions and in the quality of these reasons.

Clearly enough in immigration cases, empirical considerations can be extremely important in justifying a specific decision, be it a positive or a negative one. ${ }^{85}$ This point about the identification of the empirical considerations is especially relevant for the Single Permit Directive and its Article 8(3) which states that "an application may be considered as inadmissible on the grounds of the admission volume of third country nationals coming for employment and, on that basis, need not to be processed." This formulation relates to a similar one in Article 75(4) TFEU, securing Member States a reserve of sovereignty in determining the volume of admission of third country nationals wanting to immigrate for work purposes. For the present argument, this term "volume" shall be understood as referring to the number of labor immigrants directly coming from a third country ${ }^{86}$ and not to those already admitted to the EU. Furthermore, Article 79(5) is only applicable to immigrants seeking "employment or self-employment," and not to categories of people willing to immigrate for other reasons. For Peers et al., this specific reserve should be interpreted as

\footnotetext{
${ }^{84}$ See Schotel, supra note 58, at 193 (suggesting this strategy in evoking "obviously proportionate decisions," but without further investigating it).

${ }^{85}$ For the importance of justifying positive decisions, see Tesseltje De Lange, The Single Permit Directive: A Limited Scope, a Simple Procedure and Limited Good Administration Requirements, in The Single Permit Directive: Central Themes and Problem Issues 5, 11 (Paul Minderhoud \& Tineke Strik eds., 2015).

${ }^{86}$ Bast, supra note 7 , at 150 .
} 
part of the general competence on immigration conferred to the EU: "It must therefore be concluded that article 79 TFEU includes the power to regulate economic migration of third country nationals, limited only by the express restriction of competence in article 79(5) TFEU". 87 This specific clause - and its implementation in the Blue Card Directive and the Single Permit Directive-is interesting because to ground a negative decision upon it would require a Member State to provide empirical background for its decision, such as the number of current labor immigrants, current figures on the unemployment rate, and current figures on situation of specific economic sectors. Following my argument, the use of this exception clause to the general competence should be (1) justified, and (2) this justification cannot be satisfactory without any empirical considerations. These expectations might be extremely minimal; they remain the point upon which to exercise pressure thanks to the joint application of proportionality and the right to reasoned decision.

The case for satisfactory information on the empirical considerations is particularly clear if one defends the instrumental framing identified above. To be able to understand and maybe challenge a specific decision requires to be informed about the empirical considerations forming the basis of the decision made. Similarly, for a Court to assess a specific decision, it is essential to have a clear view of the empirical considerations drawn upon by the public authority. The case is at first glance less obvious if one defends a non-instrumental reading of the right to get a reasoned decision-the one called "Aristotelian" by Mashaw_but it might nevertheless be made plausible. A justification, which does not mention any of the empirical considerations that ground the decision, might be said to be disrespectful of the status of the person as reasons-bearers. The person has a claim to understand the decision that affected them, and this is not possible without a clear view on the empirical considerations.

In its case law, the CJEU has regularly mentioned that the right to get reasons should be conceived as encompassing both the legal and factual elements that sustain a specific decision. Following the instrumental interpretation identified above, the Court has linked this necessity to its own capacity to take a position while assessing a specific decision. Recalling the importance of procedural guarantees, the CJEU stated that,

those guarantees include, in particular, the duty of the competent institution to carefully and impartially examine all the relevant aspects of the individual case, the right of the person concerned to make their views known and to receive an adequately reasoned decision. Only in this way can the Court verify whether the factual and legal elements upon which the exercise of the power of appraisal depends were present. $^{88}$

By analogy, the CJEU has stated that, in a case on competition law enforcement, the "statement of reasons is to be considered sufficient if it clearly and coherently indicates the considerations of fact and of law on the basis of which the fine has been imposed on the parties concerned." 89 This view is also defended in Article 18 of the non-binding European Code of Good Administrative Behaviour-the duty to state the grounds of decisions-stating "[e]very decision of the institution which may adversely affect the rights or interests of a private person shall state the grounds on which it is based by clearly indicating the relevant facts and the legal basis of the decision." 90

\footnotetext{
${ }^{87}$ Steve Peers et al., EU Immigration and Asylum Law: TeXt and Commentary 14 (Leiden, 2012); Bast, supra note 7, at 152 (By contrast, Bast sees in Art. 79(5) an important instrument to diminish conflict potential on the further development of the EU immigration policy).

${ }^{88}$ Case C-269/90, supra note 74 .

${ }^{89}$ Case C-41/69, ACF Chemiefarma NV v. Comm'n of the European Communities, 1970 E.C.R. 661.

${ }^{90}$ The European Ombudsman, European Code of Good Administrative Behaviour, 21 (2015), https://osha.europa.eu/en/ about/good-administrative-behaviour/annex1-european-ombudsman-code-of-good-administrative-behaviour.pdf.
} 


\section{Giving reasons in light of proportionality}

Coming back to the example of the Single Permit Directive and the right of Member States to determine volumes of admission, my analysis allows me to highlight more clearly the duty of the public authority to rely upon certain empirical considerations in order to use this specific norm. Let us imagine that a national authority makes the decision to decline the application of our IT specialist because it estimates that already too many applicants have applied in this specific economic sector. It delivers a negative decision on the application, briefly presenting the legal basis-among others, Article 8(3) Single Permit Directive and Article 6 Blue Card Directive - and explaining its reasoning, for example its sovereign right as national authority to protect its job market or the like. For the sake of the argument, let us assume an extreme case in which the public authority does not give any information on the empirical basis of its decision. In this case, the strategy of "starting at the extremes" would challenge the fact that a justification without empirical data is acceptable. Although the decision massively relies upon empirical data, there is no evidence of them. This total absence of data is problematic with respect to the capacity of the affected person to understand and challenge the decision, but also highly questionable with respect to the ambition of a good administration of the law and as to the compatibility with the status of persons as reasons-bearers. It is important to see that the two framings identified above-instrumental and Aristotelian-converge in a concrete case, although the ultimate justifications for the "problem" might differ. The most important for my argument is that they concur in enabling a dynamic movement.

The dynamic movement set in motion by proportionality would at first directly challenge the missing empirical data. This data must be made explicit as part of the decision. This might include figures on the national unemployment rate, a specific economic sector, or immigration statistics. This first stage is not about challenging the relevance of the data, but only about making them appear as essential elements of the application of the law. Interestingly, a much clearer procedural guarantee was entailed by the proposed comprehensive Directive on legal immigration, however, this was withdrawn in 2006 due to missing political support. ${ }^{91}$ It contained a procedural guarantee according to which the given reasons should be "based upon objective and verifiable criteria on which the decision is based." 92 This formula entailed a clear reference to empirical elements. This broad procedural guarantee was linked to the requirement foreseen by the Directive to conduct tests which clearly relied upon an empirical data "economic needs test" and "beneficial effects test" and which, therefore, made these elements an important part of a putative assessment.

The second stage of the dynamic movement is about challenging how the public authority interprets this data. Given the identification of specific data—say the unemployment rate-why does the public authority consider it problematic or how does it fit into the delivered decision? This specific example illustrates that the advantages of the proportionality challenge might only appear midterm. By pushing the public authority to explicitly state its interpretation of the data, proportionality makes this interpretation part of the application of the law and is hence recorded as such. It integrates a specific interpretation of empirical data into the institutional functioning of the law. The importance of this publicity was noted by AG Kokott in the Mellor case:

The provision of reasons is not exclusively in the interest of the citizen, moreover it also effects an initial self-check on the side of the administration and can pacify relations with the citizen, since if the reasons are convincing, they put an end to existing conflicts and prevent superfluous legal disputes. ${ }^{93}$

\footnotetext{
${ }^{91}$ Proposal for a Council Directive on the Conditions of Entry and Residence of Third-Country Nationals for the Purpose of paid Employment and Self-Employed Economic Activities, 2001 O.J. (C 332).

${ }^{92}$ TFEU art. 29(4); See also the Code proposed by Steve Peers, An EU Immigration Code: Towards a Common Immigration Policy, 14 Eur. J. of Migration \& L. 33, 46 (2012).

${ }^{93}$ Case C-75/08, The Queen, on the application of Christopher Mellor v. Sec'y of State for Communities \& Local Gov't, 2009 E.C.R. I-03799.
} 
In the future, the public authority will be bound by its former declarations on this data. In that sense, proportionality creates the conditions for a better administration of the law in giving strong incentives to public authority to be cautious and, most importantly, consistent when interpreting data in justifying decisions.

\section{Criticism}

To conclude this second part, we shall address an important line of criticism, which can be expressed in a simple question: Why do we need proportionality for that argument? As for other procedural rights, the right to reasoned decision could and arguably should be improved, without drawing upon the complex argument on proportionality. I see two lines of reply to that criticism. The first acknowledges that improving the right to reasoned decision is indeed a good idea. Nevertheless, there is a requirement to mobilize a normative argument in order to show that the current stand is not satisfactory and in order to justify what should be changed. In order to move the right to a reasoned decision into a specific direction, we need a normative point of reference upon which to base the argument. This Articles argument has highlighted one potential point of reference: Proportionality. As a widely recognized normative device, proportionality offers a strong basis to improve the right to a reasoned decision. In brief, this first line of reply would strengthen the idea that something needs to work in the background of the argument, and that this something could well be proportionality. ${ }^{94}$ It is a question of transparency in legal arguments to make the normative resources used in interpreting a legal concept—such as the right to reasoned decision-as clear as possible and in trying to reform it. To make this point more tangible, take again the case law by the CJEU on the right to a reasoned decision. As explained when dealing with the requirement to inform about empirical considerations, there is a margin of appreciation as to whether the affected person or entity has information of a sufficient quality. In this sense, the CJEU clearly states that there is an upper-limit to this legitimate demand. In a recent decision on a complex claim on failing to respect subsidiarity in the enactment of a new Directive - raised by Estonia - it noted that "more particularly, it is not possible to require that the statement of reasons should set out the various facts, often very numerous and complex, on the basis of which a directive was adopted, or a fortiori that it should provide a more or less complete evaluation of those facts." $"$ Indeed, what might be expected is the function of different criteria in the specific case, ${ }^{96}$ such as the type of decision at stake-legislative, regulatory, individual decision-the complexity of the empirical elements, and the early integration of the different stakeholders in the decision-making process. ${ }^{97}$ Notwithstanding this specific case, what is interesting is the margin of appreciation in addressing the due (1) number and (2) quality of factual information. For the present argument, this makes our point clear: The principle of proportionality might be drawn upon in channeling legitimate disagreements on these two points. It creates the normative space in which to identify and account for the different rationales in determining the quality of the due justification. This relevance is especially clear in cases where administrative or judicial bodies - or even legislative body in the EU, as in the Estonian casehave an important power of appraisal. ${ }^{98}$ In those cases, the risk of arbitrary decisions is higher

\footnotetext{
${ }^{94}$ See Robert Alexy, supra note 69, at 9. A parallel might be established with the argument on "claim to correctness" proposed by Alexy. Applying proportionality—especially in context of fundamental rights—might bring order and rationality into the law by requiring it to make explicit the reasons of a specific interpretation.

${ }^{95}$ Case C-508/13, Republic of Estonia v. European Parliament and Council of the European Union, 2015 EUR-Lex CELEX LEXIS 403 (June 18, 2015).

${ }^{96}$ Schwarze, supra note 75 , at 140.

${ }^{97}$ For the latter element, Joined Cases 78/16 and 79/16, Giovanni Pesce \& Others v. Presidenza del Consiglio dei Ministri Dipartimento della Protezione Civile \& Others, 2016 EUR-Lex CELEX LEXIS 428 (June 9, 2016); See generally Ingrid Opdebeek \& Stephanie De Somer, supra note 72, at 123-24.

${ }^{98}$ Schwarze, supra note 75 , at 1406.
} 
than in situations with strict rules for decision-making. This explains why the right to a reasoned decision is considered to be more important in cases with danger of arbitrariness. ${ }^{99}$ This can of course be extremely relevant for immigration matters, which are characterized by a strong claim to unilateral appraisal by a Member State. Beyond this substantial point, my argument is about the relevance of proportionality as a jointly applied principle to organize and rationalize our disagreements on how this right to reasoned decision should be further developed.

The second line of reply will more clearly link proportionality and the protection of individual freedom. It might also be considered in the continuation of the first line of reply: It takes a stronger position on the substantial effect which proportionality might have. Indeed, proportionality is never a neutral device, it is interpreted as a normative device to organize our normative disagreements about the limits imposed on individual freedom by a public authority. ${ }^{100}$ First, this structuring effect is by no means morally neutral. This will be a faulty equation with what Letsas calls "instrumental rationality." 101 Second, proportionality might not be understandable, let alone actionable, without a position on what freedom means. In other words, it represents a widely accepted legal concretization of the principle of freedom. ${ }^{102}$ If one accepts this plausible characterization of proportionality - which would need to be fully argued for-it then appears that its application in conjunction with other procedural guarantees-in casu, the right to reasoned decision-is in fact an attempt to extend procedural guarantees in pushing a freedom-based argument. Again, as explained above, our argument does not assume the existence of a right to immigration based upon individual freedom. To assume this right would indeed make the application of proportionality easier and more direct. But because this right does not exist yet, proportionality bears upon secondary interests created by the existence of a legal venue-as the Single Permit procedure. In that dimension, it exercises normative pressure as an Ersatz for an argument focused on the freedom to immigrate. The strength of proportionality appears in its unveiling function and in the fact that it forces the involved parties to find some common ground, without having to first make plausible a substantial ideal of freedom and a right to immigration. It injects the value of individual freedom into our debates on the scope of procedural guarantees.

\section{Conclusion: challenging a sense of discretion in immigration}

This Article has argued that the general principle of proportionality was applicable to the majority of labor immigration applications to the EU. It has exemplified which types of consequences are thinkable in arguing for a joint application with the right to reasoned decision. Applied together, these two widely accepted principles might transform the way procedural guarantees are applied in immigration cases.

The first objective of this Article was to present an argument for the purpose of strategic litigation on the Single Permit Directive. This objective has been achieved by highlighting, in a new perspective, the potential of a stronger cooperation between the principles of proportionality and procedural guarantees. The argument proposed for the right to reasoned decision is applicable to other procedural guarantees. Due to the strong link between proportionality and the protection

\footnotetext{
${ }^{99}$ Case C-269/90, supra note 74 .

${ }^{100}$ This has not always been the case and commentators highlight the global rise of use of proportionality in constitutional contexts. Schwarze, supra note 75 , at 1410 .

${ }^{101}$ In the context of human rights and the different values embodied by them, Letsas makes this point in the following way: "Proportionality, in its normative sense, can track a variety of moral reasons and applies to a variety of moral practices. Its semantic content is subservient to the moral value that governs the domain in question (e.g. democracy or desert in punishment)." George Letsas, Rough Proportionality, in Philosophical Foundations of Human Rights 316, 320 (Rowan Cruft, et al. eds., 2015).

${ }^{102}$ See Franck, supra note 80 , at 716.
} 
of individual freedom, it might be applied in conjunction with guarantees that pursue a broadly similar objective. And because of the relevance of the Single Permit Directive to almost all labor immigration applications, the argument may prove to be widely relevant.

The second objective of the Article was to contribute to the broader issue of the sovereign claim raised by the EU and its Member States in regulating immigration. In political terms, a decision on labor immigration matters is still conceived from the point of view of an almost completely discretionary State. This makes labor immigration very different from the fields of asylum or family reunification; the State makes a strong claim to unilaterally decide who is allowed on its territory for work purposes. In other words, the maxim of "chosen immigration" seems to perfectly grasp the claims raised by the State.

In brief, there are two strategies to address this type of claim: To attack it frontally or to control its main problems. The first strategy has been the focus of the ethics of immigration for the last 30 years. Political philosophers have raised serious doubts about the legitimacy of the State to define its immigration policy in the first place. Challenging the core competence of the State in immigration matters might indeed appear as a bold move. ${ }^{103}$ From the perspective of the ethics of immigration, this Article might be read as a rejoinder for legal theorists and practitioners alike. In a nutshell, the strategy is not to frontally question the competence of the EU and its Member States to decide upon labor immigration applications, but rather to focus on the implications of their own commitments - mainly instantiated in form of principles — on the way they have to deal with applications for immigration.

According to this taming strategy, the conjunction of two crucial principles to which the EU has long been committed appears as the most powerful way to mobilize internal resources to criticize a certain view of the sovereign competence of the political community in immigration matters. On the one hand, there is no requirement to argue from an external point of viewfor example trying to push the existence of a human right to immigration. The normative work is done from within the existing EU legal order, on the basis of its own legal concepts. On the other hand, the argument makes the most out of procedural guarantees. It does not attempt to achieve a revolution, but rather relies upon incremental changes, which in turn rely upon bit-by-bit improvements on how affected individuals who are external to the political community are considered-respectively, their applications. The principle of proportionality might be the best candidate to organize and channel this incremental strategy. As explained by Stone Sweet and Mathews, proportionality applied by judicial actors is especially efficient in managing "potentially explosive environments" while establishing, and then reinforcing, "the salience of constitutional deliberation and adjudication within the greater political system." ${ }^{104}$ In this light, its joint application with the right to reasoned decision appears especially promising: The quality of the justification delivered by a public authority is a crucial element of this incremental improvement strategy. The relevance of giving good and sufficient reasons to affected individuals is at the core of this strategy. Mashaw grasps a similar idea when he writes: "The judicial demand for reasons has become a legitimate procedural version of an otherwise illegitimate substantive demand for reasonableness, as judicially determined." ${ }^{05}$ This idea sketches the necessary cooperation between the different strands of arguments from a different perspective, by questioning the discretionary handling of immigration. The dimension of "reasonableness" shall be addressed, mainly by the ethics of immigration and the fundamental challenge of the State's

\footnotetext{
${ }^{103}$ For this idea see Veit Bader, The Ethics of Immigration, 12 Constalations 331 (2005); Jonathan Seglow, Immigration, in International Encyclopedia of Ethics (Hugh Lafollette ed., 2013); Alex Sager, The Ethics and Politics of ImMigration: CORE ISSUES AND EMERging TREnds. (Lanham, Rowman \& Littlefield International ed. 2016); Christopher Heath Wellman \& Phillip Cole, Debating the Ethics of Immigration: Is There a Right to EXCLUDE? (Oxford Universtiy Press, 2011).

${ }^{104}$ Stone Sweet, supra note 81 , at 88.

${ }^{105}$ Mashaw, supra note 76 , at 111.
} 
competence to regulate immigration. In the meantime-and to complement-the procedural dimension of "reasons-giving" shall be addressed by a contribution focusing on the legal resources already available when interpreting and implementing the current EU law on immigration. ${ }^{106}$ The legal realizations of the commitments of the EU and its Member States, in their long tradition of individual freedom protection, should be the bedrock of this incremental strategy of internal current immigration law criticism.

\footnotetext{
${ }^{106}$ For the broader idea of a "legal turn" in immigration ethics, see Johan Rochel, Towards a Legal Turn in the Ethics of Immigration, 4 DE ETHICA 31 (2017).
}

Cite this article: Rochel J (2019). Working in tandem: Proportionality and procedural guarantees in EU immigration law. German Law Journal 20, 89-110. https://doi.org/10.1017/glj.2019.1 